\title{
Factors affecting beef consumption in the valley of Mexico
}

\author{
Ricardo Tellez Delgadoํ, José Saturnino Mora Flores ${ }^{1}$ \\ ${ }^{1}$ Colegio de Postgraduados, Montecillo, Texcoco, Estado de México, México.

\begin{abstract}
The objective of this study was to know the factors that determine the consumption of beef in the Metropolitan Area of the Valley of Mexico, using logit and probit modeling (nominal variable) with 400 surveys. The results showed that significant variables that determine the probability of purchasing beef are schooling, number of members per family, meat preference, family income, and presence of disease in the individual. The largest marginal effects on the purchase decision were provided by the income and the meat preference variables, while the price was not significant. The main factors that determine the consumption of beef are schooling and the number of members in the family, while the meat preference and income are dismissed.
\end{abstract}

Key Words: consumer, logit, meat, model, probit

\section{Introduction}

Foods consumed by humans are of agricultural or livestock origin, and one of them is beef, which is an important nutritional component composed of protein, minerals (potassium, phosphorus, and iron), and vitamin (B) for the proper functioning of the human body (SE, 2006). The largest beef producing countries in the world are the United States (19.3\%), Brazil (11.2\%), China $(10.0 \%)$, Argentina (4.2\%), and Australia (3.4\%), and in sixth place is Mexico (2.8\%) (Financeira Rural, 2012). In 2011, the beef production worldwide was 3.4 million tons; exports were placed at 113 thousand tons and imports at 251 thousand tons, representing a deficit in beef, although in recent years exports have been increasing and imports decreasing (Financiera Rural, 2012). In Mexico, the main states with increased livestock production, which account for $42 \%$, are Veracruz, Jalisco, Chiapas, Chihuahua, and Sinaloa (SIAP, 2012).

According to a study by UACH (2008), the livestock activity of beef production in Mexico has shown a strong technological and industrial development, which results in increased availability of basic food for a growing population also. Beef cattle production in the country takes place in various agro-ecological conditions, mainly influenced by

Received April 25, 2014 and accepted June 12, 2015

Corresponding author: saturmf@colpos.mx

http://dx.doi.org/10.1590/S1806-92902015001000005

Copyright (C) 2015 Sociedade Brasileira de Zootecnia. This is an Open Access article distributed under the terms of the Creative Commons Attribution License (http://creativecommons.org/licenses/by/4.0/), which permits unrestricted use, distribution, and reproduction in any medium, provided the original work is properly cited. climatic factors of each region. Therefore, there are various systems in the country to obtain meat: intensive or feedlot farming, and extensive or fattening performed on pastures and rangeland and semi-intensive systems.

According to the Service for Food and Fisheries Information (SIAP), in 2012, Mexican households spent $22.7 \%$ of their spending in food. Of this expenditure, 0.0784 in 0.2352 dollar was used to purchase livestock products (poultry, turkey, pig, cattle, sheep, and goat meats).

On the total volume by types of meat consumed by the Mexican population, beef occupies $28 \%$; poultry, $41 \%$; pork, 26.5\%; and other types of meat (sheep and goat mainly), $4.5 \%$ (SIAP, 2012).

The main beef market in Mexico is the Metropolitan Area of the Valley of Mexico, where, with 20 million inhabitants, consumption is $40 \%$ and marketing represents $70 \%$ of the national total (FIRA, 2003). This region is supplied with meat from cattle fattened in some neighboring municipalities of the state of Mexico (San Vicente, Los Reyes, and Ecatepec), which still have rural areas (supplying nearly 19\%). Another significant proportion of meat comes from the FIT slaughterhouses in the states of Veracruz, Jalisco, Chiapas, Tabasco, Sonora, Chihuahua, and Sinaloa (SIAP, 2012).

The Metropolitan Area of the Valley of Mexico (MAVM) is the main center of national beef consumption; thus, the objective of this study was to know the characteristics of the meat considered by the consumer when making their purchase. The working hypothesis states that the price is not the only attribute that determines the purchase, but that there are also other aspects of beef conditioning such as schooling, number of family members, meat preference, and income. 


\section{Material and Methods}

The study was conducted in the Metropolitan Area of the Valley of Mexico (MAVM), which included 16 sections of the Federal District (Álvaro Obregón, Azcapotzalco, Benito Juárez, Coyoacán, Cuajimalpa, Cuauhtémoc, Gustavo A. Madero, Iztacalco, Iztapalapa, Magdalena Contreras, Miguel Hidalgo, Milpa Alta, Tláhuac, Tlalpan, Venustiano Carranza, and Xochimilco) and eight municipalities in the metropolitan area of the state of Mexico (Atizapán de Zaragoza, Cuautitlan Izcalli, Coacalco, Cuautitlan, Chalco, Chicoloapan, Chimalhuacán, Ecatepec, Huixquilucan, Ixtapaluca, La Paz, Nicolás Romero, Naucalpan, Nezahualcoyotl, Tecámac, Tlalnepantla, Tultitlan, and Valle de Chalco). The analysis was performed using a qualitative regression model, which allows us to find the probability of an event happening: these probabilistic models express that if $\mathrm{X}_{\mathrm{i}}$ increases, $\mathrm{P}_{\mathrm{i}}=\mathrm{E}(\mathrm{Y}=1 \mid \mathrm{X})$ will also increase, but will never leave the 0-1 interval (Gujarati, 2003). In these models the dependent variable is dichotomous and the independent variables can be encoded as intervals or be categorical, i.e., values of a variable that can only take two values are predicted. The cumulative distribution functions representing response patterns 0 or 1 are logistic (Logit) and normal (Probit).

The logistic function of the cumulative Logit model has the following form:

$$
P_{k}=E\left(Z=1 \mid X_{k}\right)=\frac{e^{-\left(\beta_{0}+\beta_{1} X_{1}+\cdots+\beta_{j} X_{g}\right)}}{1+e^{-\left(\beta_{0}+\beta_{1} X_{1}+\cdots+\beta_{j} X_{g}\right)}}
$$

in which $P_{k}$ is the probability of an event happening; $\beta_{\mathrm{j}}(\mathrm{j}=0,1,2, \ldots, \mathrm{k})$ are the calculated coefficients; and, finally, $X_{k}$ represents the set of variables that describe the characteristics of the interviewed consumer.

The Probit model (known as normit) uses a standard normal distribution, which has a greater difficulty for its calculation, because it is an integral (Sánchez, 2012).

$$
F(Z)=\left(\frac{1}{\sqrt{2 \pi}}\right) \int_{-\infty}^{\mathrm{Ii}} \mathrm{e}^{-\mathrm{Z}^{2} / 2 \mathrm{dz}}
$$

Each parameter $\left(\beta_{\mathrm{j}}\right)$ indicates the direction in which the probability moves when the explanatory variable increases, plus the parameters quantify the marginal effects of the indirect variables on the probability of the dependent variable. Economic theory suggests that the marginal effect expresses that the effect on the dependent variable causes a small change in an independent variable, ceteris paribus (all else constant) (Wooldridge, 2008).

The model's ability to classify individuals who consume beef from those who do not is called discriminatory power.
The ROC (Receiver Operating Characteristics) curves are the graphical representation of discriminatory power; the more a curve approaches the upper left corner, the higher is the overall accuracy of the test (Escalona, 2011). The area under the ROC curve coincides with the probability that the identification of individuals in the sample is adequate.

The sample calculation took into account the total population interviewed in the Metropolitan Area of the Valley of Mexico, which was 18,240,060 inhabitants, according to the Population and Housing Survey of INEGI (2005). The sample size was obtained by the following equation:

$$
\mathbf{n}=\frac{(p)(q)(N)\left(Z^{2}\right)}{E^{2}(N-1)+Z^{2}(p)(q)}
$$

in which $\mathrm{N}$ is the total population of the universe of study $(18,240,060$ inhabitants $) ; \mathrm{n}$ is the sample size; $\mathrm{p}$ is the estimated percentage of positive variability $(50 \%)$; $\mathrm{q}=100-\mathrm{p}$ (negative variability); $\mathrm{E}$ is the error or precision of estimation allowed (5\%); and $\mathrm{Z}$ is the confidence level: $\mathrm{Z}$ of squares $=1.96$.

The calculated size of the sample was 400 interviews and a non-probability quota sampling was applied. The criterion for selection of individuals was their available disposition to be interviewed. The 400 questionnaires were completed in delegations and municipalities, which were ranked from high to low population density. Individuals were interviewed in butcher shops, public markets, shopping centers, parks, and food establishments.

The variables in the survey were considered by blocks: 1) in the first block, name, place of birth, sex, age, schooling, and number of family members were asked; 2 ) in the second block, questions were asked about the family income, and amount and income destined to the purchase food and meat, preferences of the type of meat (poultry, beef, and pork), restrictions on eating meat, frequency (weekly or monthly) of meat consumption, type of pieces or cuts consumed, prices, places of purchase, services added to the meat, etc.

Data from the interviews were collected during the first quarter of 2010 and were captured in a structured Excel ${ }^{\complement}$ spreadsheet template, which was analyzed to create models with the SAS (Statistical Analysis System, version 9.3) software package.

\section{Results and Discussion}

With the information obtained from the questionnaire used, an analysis of relative frequencies was performed, noting that the sample of interviewed consumers consisted 
mainly of women (91.1\%) with an average age between 30 and 59 years, and the families were composed of three or four members.

With respect to the food purchase decision for the home, $87.7 \%$ of those interviewed make the decision, a result similar to that of Segovia (2005) and Schnettler et al. (2006) in Venezuela and Chile. Regarding the sex, the female (housewife) is the gender which decides to purchase meat. In addition, $56.4 \%$ of individuals in the MAVM spend 21 to $50 \%$ of household income on food, whereas $30 \%$ use only $20 \%$ of the family income for this purpose.

The meat consumption by the population is $79.5 \%$ beef, and the majority (46.8\%) consumes it on average six to 15 times a month, while $28.0 \%$ have a low consumption, of 5 times or less per month. This is similar to what is described in the study of Vilaboa et al. (2009), who reported that consumers of the Region Papaloapan in Veracruz $(60.1 \%)$ consume beef two to three times a week, due to the preference for its flavor, variation of dishes or diet, and nutritional value.

An important item is the level of monthly income of consumers, in which $51.4 \%$ of respondents have a low income (392 dollars ${ }^{1}$ or less), 36.4\% have a medium income (392 to 1.176 USD), and only $12.4 \%$ have a high income (over 1,176 USD). According to a study by Núñez et al. (2010) on the socio-economic factors that determine the consumption of beef in two cities of Chihuahua, $70.3 \%$ of the inhabitants of the cities of Cuauhtemoc and Delicias receive an income of 470 dollars or less, and $76.4 \%$ have an income of 705 dollars or less. On the other hand, Vilaboa et al. (2009) mentioned in their study that $51.0 \%$ of consumers of beef in Papaloapan declared to earn an income of under 470 dollars per month; these results were similar to those obtained in MAVM.

According to the interviewees, $74.3 \%$ have no restrictions for consuming any type of meat (beef, pork, and broiler), while $25 \%$ showed constraints to consume mainly beef and pork and who are people aged over 60 years. The reasons for not consuming these meats are mainly high cholesterol (4.8\%), diabetes $(2.7 \%)$, high blood pressure $(2 \%)$, and high uric acid $(1.8 \%)$. This is consistent with results reported by Schnettler et al. (2008), which showed that older people significantly reduce the consumption of beef and veal, pork, and lamb, which are replaced by white meat, associated with a lower risk of disease. ${ }^{1}$ Average exchange rate from January 1 to December 5, 2013. One Dollar $=12.75442$
pesos (Banxico, 2013).
Two options were raised in the modeling of the probability that the interviewed person consumed beef: a) he/she consumes denoted by 1 (success), and b) he/she does not consume, denoted by the value 0 (failure). In the construction of the Probit and Logit models, the variables schooling (ESC), number of members per family (NFAM), preference for meat (PREFCAR), presence of disease in the individual (ENF), family income (ING), and meat prices (PREC) were used.

In the case of the Logit model, the Hosmer-Lemeshow test was used; this test sets the deciles of risk or probability of the event, estimated by the model. If there is a high coincidence between observed and expected data, the chi-square statistic that contrasts both distributions will not show significance for the hypothesis testing, in which Ho represents that all coefficients are equal to zero, and a good model fit is achieved (Escalona, 2011). Therefore, for this case, the statistical P-value was 0.8299, indicating a good fit. For the same model, the likelihood ratio chisquare was 356.75 and $\mathrm{P}<0.0001$, which shows that it fits significantly (Guerrero, 2007). As to the fit of the Probit model, we used the Likelihood Ratio Index (LRI), also called McFadden's $\mathrm{R}^{2}$. The obtained value was 0.80031 , confirming the good fit of the model according to Herbert (2009), which states that a fit greater than 0.1 is considered appropriate (Table 1).

The ROC curve expresses the discriminatory power, which, in the case of the Logit model, was $98.75 \%$ of concordant pairs and an area under the curve of 0.9875 , which yields results of excellent discriminatory power (Escalona,2011), because the more the curve approaches the upper left corner, the higher the accuracy of the test (Figure 1)

In the chi-square test, with a significance level of 0.05 , four variables were significant statistically: schooling (ESC), number of members per family (NFAM), preference for meat (PREFCAR), and family income (ING). Two variables were excluded from the model for not being significant, with $\mathrm{P}>0.05$. The results of the Logit and Probit models showed no difference in quantitative terms (Table 2).

Table 1 - Statistics of fitting of the models

\begin{tabular}{|c|c|c|c|}
\hline Model & \multicolumn{2}{|c|}{ Indicator } & Statistical value \\
\hline \multicolumn{3}{|c|}{ Hosmer-Lemeshow } & 0.8299 \\
\hline \multirow[t]{2}{*}{ Logit } & \multirow[b]{2}{*}{ Likelihood ratio } & Chi-square & 356.7525 \\
\hline & & $\operatorname{Pr}>$ ChiSq & $<0.0001$ \\
\hline Probit & \multicolumn{2}{|c|}{ Likelihood ratio index (ICV) } & 0.80031 \\
\hline
\end{tabular}

Source: made by the authors with estimates of the SAS 9.3 statistical package. 
Taking the estimates in Table 2, the Logit model for the probability of occurrence of the event (consumption) is shown below:

$\mathrm{P}_{\mathrm{k}}=\mathrm{E}\left(\mathrm{Z}=1 \mid \mathrm{X}_{\mathrm{g}}\right)=\frac{\mathrm{e}^{-(-0.9232+0.5095 E S C+0.3691 N F A M-0.7022 P R E F C A R-0.7329 I N G)}}{1+\mathrm{e}^{-(-0.9232+0.5095 E S C+0.3691 N F A M-0.7022 P R E F C A R-0.7329 I N G)}}$

According to Escalona (2011), the predictive power is the ability of the model to predict the dependent variable based on the values of the independent variables. The $\mathrm{R}^{2}$ value of 0.5555 was used to evaluate the predictive power of the model, indicating a regular predictive power.

The Probit model estimated was substituted in formula 2: $\mathrm{F}(\mathrm{Z})=\left(\frac{1}{\sqrt{2 \pi}}\right) \int_{-\infty}^{\mathrm{Ii}} \mathrm{e}^{-(-0.5066+0.28295 E S C+0.2119 N F A M-0.4034 P R E F C A R-0.4297 I N G)^{2} / 2} \mathrm{dz}$

Schooling (ESC) was one of the significant variables in the model of beef consumption in MAVM. This variable with positive effect indicates that consumers with a higher level of education are willing to consume more meat because of the high educational level and labor jobs with greater economic remuneration. This agrees with Taddei et al. (2012), indicating that consumers with a higher academic level (professional) consume more beef.

Another variable that impacted the consumption of beef in MAVM positively is the number of members per family (NFAM). Addressing this, Schnettler et al. (2008) reported that families of three to four members consume more beef, as they are not made up of children under 12 years. Also, Núñez et al. (2010) stated that there is a very definite relationship between the amount of consumed beef and the size of the family, especially those of two to five members, and also that the number of members is a significant factor in the household at the time of decision to purchase meat (Schnettler, 2006).

The variable that expresses the meat preference (PREFCAR) by consumers has a negative impact, as they prefer poultry meat because of the risk of eating red meat in the center of Mexico. According to Arenas et al. (2010), in MAVM, $96.6 \%$ of the population prefers and consumes chicken, which is attributed to its low price and low fat content. However, Taddei et al. (2012) reported that, in
Northeastern Mexico, where beef is the main preference, the consumer's reason is "for its taste and flavor", followed by health reasons.

Income (ING) was another variable that had a negative effect on beef consumption. This indicates that low-income consumers are not willing to consume beef because of the high price of the product. In this regard, Núñez et al. (2010) mention in their study that $10 \%$ of consumers with incomes under 235 dollars consume less than a kilo of beef per week, i.e., meat is a luxury for the poor and the less purchasing power, the less the meat consumption. Tellez et al. (2012) and Benítez et al. (2010) mention that income and consumption are positively correlated in developing countries like Mexico; when income increases so does spending on consumption and the demanded quantity of beef. Also, Mahecha et al. (2002) found that in Colombia the consumption of beef is determined by the income.

Another variable that conditioned the purchase of beef is price (PREC), and for the MAVM interviewees, it was not significant. However, Schnettler et al. (2004) found in

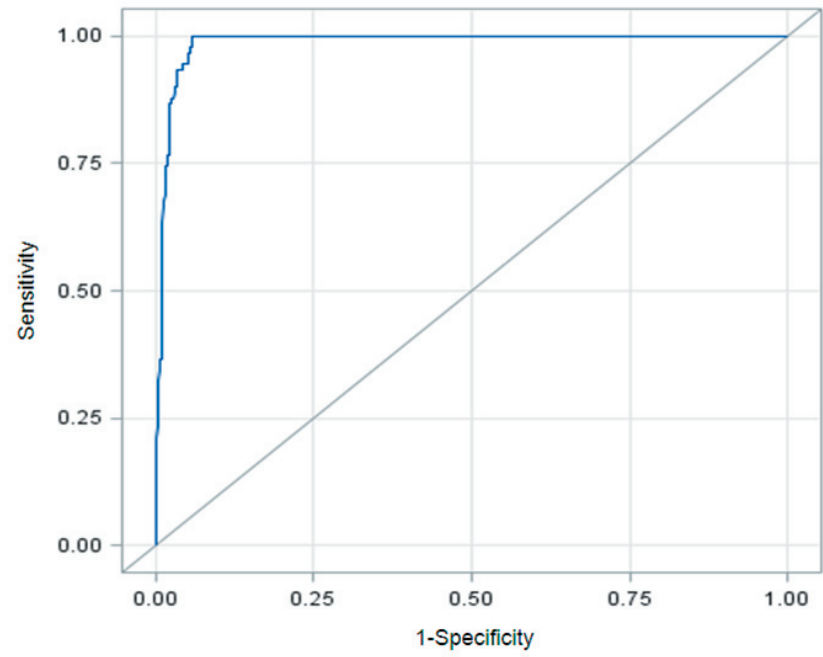

Source: made by the authors with the SAS 9.3. statistical package.

Figure 1 - Receiver Operating Characteristic (ROC) curve.

Table 2 - Estimates of the parameters of the Logit and Probit models

\begin{tabular}{|c|c|c|c|c|c|c|}
\hline \multirow{2}{*}{$\frac{\text { Model }}{\text { Parameter }}$} & \multicolumn{3}{|c|}{ Logit } & \multicolumn{3}{|c|}{ Probit } \\
\hline & Coefficient & Wald Chi-Square & $\operatorname{Pr}>$ ChiSq & Coefficient & Chi-Square & $\mathrm{Pr}>\mathrm{ChiSq}$ \\
\hline Intercept & -0.9232 & 0.4326 & 0.5107 & -0.5066 & 0.39 & 0.5315 \\
\hline ESC & 0.5095 & 5.3876 & 0.0203 & 0.2829 & 5.37 & 0.0205 \\
\hline NFAM & 0.3691 & 5.4699 & 0.0193 & 0.2119 & 5.74 & 0.0165 \\
\hline PRECAR & -0.7022 & 4.3893 & 0.0362 & -0.4034 & 4.08 & 0.0434 \\
\hline ING & -0.7329 & 4.4532 & 0.0348 & -0.4297 & 4.62 & 0.0316 \\
\hline
\end{tabular}

Source: made by the authors as estimates of the SAS 9.3 statistical package. 
their study that the third attribute in importance is the price on the purchase decision, with $24.5 \%$ of responses given by consumers in Temuco, Chile. Vilaboa et al. (2009), on the other hand, assert that consumers vary their consumption according to the availability of money, and their interest of purchasing varies according to the amount and price of beef.

Regarding the signs of the estimated parameters of each variable, they indicate the direction in which the probability moves when the explanatory variable increases - in this case, the consumption of beef. For the variable PREFCAR, its coefficient is negative, indicating that consumption decreases when poultry or pork are preferred, having a direct relationship; in the same way, the consumption is reduced for the variable ING when family income decreases, ceteris paribus, respectively.

The coefficients have no direct interpretation, but can be used to quantify the marginal effects of the explanatory variables in the consumption of beef, using the value given by the sample means of independent variables. Illustrating variable NFAM, a point of increase for the previous variable with Logit model increases the probability of consuming beef at $0.012 \%$, while in the Probit model an increase of $0.0119 \%$ is recorded (Table 3). The marginal effect of the variable ING is $0.0238 \%$ (Logit) and $0.0242 \%$ (Probit), indicating that consumers are willing to increase their consumption of meat in those proportions, if this variable increases by one percentage point.

Table 3 - Marginal effects

\begin{tabular}{lcc}
\hline Variable & Logit & Probit \\
\hline ESC & 0.0166064 & 0.0159382 \\
NFAM & 0.0120303 & 0.0119382 \\
PREFCAR & -0.0228872 & -0.0227270 \\
ING & -0.0238878 & -0.0242088 \\
\hline
\end{tabular}

Source: made by the authors as estimates of the SAS 9.3 statistical package.

\section{Conclusions}

The main factors that determine the probability of beef consumption with a positive relationship in the Metropolitan Area of the Valley of Mexico are schooling and the number of members in the family, while the preference for consumption of poultry or pork, and reduction of income dismiss the consumption of beef. The factor beef price is not an important factor for consumers when deciding to purchase the product. The largest marginal effect on the purchase decision is present when income is increased, followed by the meat preference, schooling, and number of members in the family.

\section{References}

Arenas, A. M.; Mora, F. J. S; García, M. R.; Tellez, D. R. and Narciso, G. C. 2010. Caracterización de consumidores de carne de pollo en la Zona Metropolitana del Valle de México. Revista Geografía Agrícola 45:49-56.

BANXICO. 2013. Banco de México. Estadísticas de tipo de cambio y resultados históricos de las subastas en línea. Available at: $<$ http://www.banxico.org.mx>. Accessed on: Dec. 2, 2013.

Benítez, R. J. G.; García, M. R.; Mora, F. J. S. and García, S. J. A. 2010. Determinación de los factores que afectan el mercado de carne bovina en México. Revista Agrociencia 44:109-199.

Escalona, A. 2011. Uso de los modelos Credit Scoring en Microfinanzas. Tesis de Doctorado. Colegio de Postgraduados. Potsgrado de Socioeconomía, Estadística e Informática Estadística. Montecillo, Texcoco, Estado de México, México.

Financiera Rural. 2012. Financiera Rural - Dirección Ejecutiva de Analisis Sectorial: Monografía de la carne de bovino. Available at: $<$ http://www.financierarural.gob.mx.>. Accessed on: Nov. 10, 2013.

FIRA. 2003. Fideicomisos Instituidos en Relación con la Agricultura en el Banco de México: Perspectivas de la Red Carne de Bovino. Available at: $<$ https://www.fira.gob.mx $>$. Accessed on: Feb. 10, 2011.

Guerrero, V. 2007. Una prueba de bondad de ajuste para la distribución logística. Tesis de Maestría. Colegio de Postgraduados. Postgrado de Socioeconomía, Estadística e Informática Economía. Montecillo, Texcoco, Estado de México, México.

Gujarati, D. 2003. Econometría. Demetrío Garmendia Guerrero y Gladys Arango Medina. 4.ed. McGraw-Hill, México. 972p.

Herbert, M. 2009. La inocuidad alimentaria en el mercado mexicano de limón persa (Citrus latifolia Tanaka). Tesis de Doctorado. Potsgrado de Socioeconomía, Estadística e Informática Economía. Montecillo, Texcoco, Estado de México, México.

INEGI - Instituto Nacional de Estadística, y Geografía. 2005. Encuesta de población y vivienda del INEGI. Available at: $<\mathrm{http}: / / \mathrm{www}$. inegi.org.mx.> Accessed on: Mar. 24, 2013.

Mahecha, L.; Gallego, L. and Peláez, F. 2002. Situación actual de la ganadería de carne en Colombia y alternativas para impulsar su competitividad y sostenibilidad. Revista Colombiana Ciencia Pecuaria 15:213-225.

Núñez, L. J. J.; Ortega, G. J. A.; Soto, Z. M. and Rodríguez, A. M. de L. 2010. Factores socioeconómicos que determinan el consumo de carne de bovino en dos ciudades en Chihuahua, México. Revista Tecnociencia Chihuahua 4:142-153.

Sánchez, C. L. 2012. La diversidad de actividades económicas de los grupos domésticos rurales en la valoración del riesgo por parte de las microfinancieras. Tesis de Maestría. Potsgrado de Socioeconomía, Estadística e Informática Economía. Montecillo, Texcoco, Estado de México, México.

Schnettler, M. B.; Manquilef, B. O. and Miranda, H. 2004. Atributos valorados en la selección de carne bovina por el consumidor de supermercados de Temuco, IX Región de Chile. Revista Ciencia e Investigación Agrícola 31:91-100.

Schnettler, M. B.; Manquilef, B. O. and H. Miranda. 2006. Hábitos de consumo de carne bovina en Tecomuco, IX Región de Chile. IDESIA 24:15-23.

Schnettler, M. B.; Silva, E. R. and Sepúlveda, B. N. 2008. Consumo de carne en el sur de Chile y su relación con las características sociodemográficas de los consumidores. Revista Chilena de Nutrición $35: 262-271$.

SE - Secretaria de Economía. 2006. México Calidad Suprema. México, D.F. 26p.

Segovia, E. 2005. Conociendo al consumidor de carne. p.665-670. In: Manual de ganadería doble propósito. González-Stagnaro y Soto, ed. Fundación GIRARZ, Venezuela. 
SIAP - Servicio de Información y Estadística Agroalimentaria y Pesquera. 2012. Base de datos pecuario en línea. Available at: $<$ http://www.siap.gob.mx.>. Accessed on: Oct. 20, 2013.

Taddei, C.; Preciado, M.; Robles, J. and Garza, C. 2012. Patrones de consumo de carne en el noroeste de México. Revista Centro de Investigación en Alimentación y Desarrollo 2:73-96.

Tellez, T. R.; Mora, F. J.S.; Martínez D. M. A.; García M. R. and García, S. J. A. 2012. Caracterización del consumidor de carne bovina en la Zona Metropolitana del Valle de México. Revista Agrociencia 46:75-86.
UACH - Universidad Autónoma Chapingo. 2008. Diagnóstico integral del sector primario para el desarrollo rural sustentable del Estado de Oaxaca. Sistema producto pecuario bovinos carne y doble propósito. México.

Vilaboa A. J.; Díaz, R. P.; Ruiz, R. O.; Platas, R. D.; González, M. S. and Juárez, L. F. 2009. Patrones de consumo de carne bovina en la Región del Papaloapan, Veracruz, México. Agricultura, Sociedad y Desarrollo 6:145-159.

Wooldridge, J. 2008. Introducción a la econometría, un enfoque moderno. 2.ed. Fuente Rojo, C. M., ed. Thomson Paraninfo S. A., España. 